\title{
TOTAL OIL CONTENT AND EPIPHYTIC DIATOM DENSITY IN SEAGRASS LEAVES Enhalus acoroides AT PANDARATAN BEACH TAPANULI TENGAH REGENCY NORTH SUMATERA PROVINCE
}

\author{
Sarah Puspita ${ }^{1}$, Sofyan Husein Siregar ${ }^{1}$, Syahril Nedi $^{1}$ \\ ${ }^{1}$ Department of Marine Science, Faculty of Fisheries and Marine Universitas Riau, Pekanbaru \\ *sarahpuspita1997@gmail.com
}

\begin{abstract}
The aimed of this study was to determine the total oil content at Pandaratan Beach, determine epiphytic diatoms density in seagrass leaves Enhalus acoroides at Pandaratan Beach, and determined the relationship between total oil content and epiphytic diatoms density in seagrass leaves E. acoroides at Pandaratan Beach. Based on the results of research conducted, the highest total oil content is in the area around the sea transportation route, namely $0.25 \mathrm{ppm}$ and the lowest total oil content is in areas far from human activity, namely $0.16 \mathrm{ppm}$. The highest epiphytic diatoms density found in areas far from human activities, namely $932.21 \mathrm{Ind} / \mathrm{cm}^{2}$ and the lowest epiphytic diatoms density found in the area around the sea transportation lines, namely $663.41 \mathrm{Ind} / \mathrm{cm}^{2}$.The relationship between total oil content and epiphytic diatoms density at Pandaratan Beach, Tapanuli Tengah Regency, North Sumatra Province has a very weak relationship $(r=0.03)$.
\end{abstract}

Keywords: Total Oil Content, Epiphytic Diatoms Density, Enhalus acoroides

\section{PENDAHULUAN}

Sumber dari pencemaran laut antara lain adalah tumpahan minyak yang berasal dari limbah industri dan aktivitas domestik yang masuk ke perairan. Lapisan minyak yang ada di permukaan air akan menghalangi masuknya sinar matahari ke dalam air sehingga proses fotosintesis oleh tanaman air menjadi terganggu. Akibatnya, oksigen yang seharusnya dihasilkan pada proses fotosintesis tersebut tidak terjadi dan kandungan oksigen dalam air menjadi menurun. Lapisan minyak pada permukaan air juga akan menghalangi difusi oksigen dari udara ke dalam air sehingga jumlah oksigen yang terlarut di dalam air menjadi semakin berkurang. Kandungan oksigen yang menurun akan mengganggu kehidupan hewan air. Hal ini menunjukkan bahwa adanya minyak pada perairan akan menurunkan kualitas perairan dan mempengaruhi kehidupan organisme di perairan tersebut termasuk diatom dan makrozoobenthos.

Diatom adalah salah satu kelompok besar fitoplankton yang banyak menarik perhatian untuk diteliti karena keberadaannya yang selalu mendominasi di wilayah perairan laut dibandingkan dengan komunitas mikroalga lainnya. Oleh sebab itu, keberadaan diatom di perairan dapat digunakan sebagai indikator pencemaran perairan secara biologi dengan melihat kelimpahannya [1].

Diatom epifit merupakan jasad-jasad yang dapat hidup melekat pada permukaan daun lamun. Organisme epifit mempunyai peranan penting dalam penyedia produktivitas perairan, karena dapat melakukan proses fotosintesis yang dapat membentuk zat organik dari zat anorganik. Organisme ini juga memanfaatkan nutrien yang ada di ekosistem lamun. 
Pantai Pandaratan adalah pantai yang terletak di Kelurahan Pondok Batu, Kecamatan Sarudik Kabupaten Tapanuli Tengah. Pantai Pandaratan ini memiliki dua ekosistem di sekitarnya yaitu ekosistem mangrove dan ekosistem lamun, yang mana ekosistem lamun yang berada di Pantai Pandaratan memiliki hamparan lamun yang luas [2-3]. Salah satu jenis lamun yang paling banyak tumbuh di Pantai Pandaratan adalah Enhalus acoroides.

Lamun E. acoroides merupakan jenis lamun yang mempunyai ukuran paling besar, helaian daunnya dapat mencapai ukuran lebih dari 1 meter. Jenis ini tumbuh di perairan dangkal sampai kedalaman 4 meter, pada dasar pasir, pasir lumpur atau lumpur [4].

Tujuan dari penelitian ini adalah untuk menentukan kandungan minyak total di perairan Pantai Pandaratan, untuk mengetahui kelimpahan diatom epifit pada daun lamun E.acoroides di perairan Pantai Pandaratan, serta untuk mengetahui hubungan kandungan minyak total dan kelimpahan diatom epifit pada daun lamun E.acoroides di perairan Pantai Pandaratan.

\section{METODE PENELITIAN Waktu dan Tempat}

Penelitian ini dilaksanakan pada bulan April 2019 di sekitar kawasan Pantai Pandaratan, Kabupaten Tapanuli Tengah, Provinsi Sumatera Utara. Sedangkan analisis kandungan minyak dan kelimpahan diatom dilakukan di Laboratorium Biologi Laut dan Laboratorium Kimia Laut Jurusan Ilmu Kelautan Fakultas Perikanan dan Kelautan Universitas Riau.

\section{Metode Penelitian}

Metode yang digunakan dalam penelitian ini adalah metode survei. Lokasi pengamatan dan pengambilan sampel berada di sekitar Pantai Pandaratan, Kabupaten Tapanuli Tengah, Provinsi Sumatera Utara. Sampel kemudian akan dibawa ke laboratorium untuk dihitung jumlah kandungan minyaknya dan diidentifikasi diatom epifit serta dihitung jumlah kelimpahan dan selanjutnya dibahas secara deskriptif berdasarkan literatur yang berkaitan dengan penelitian

\section{Prosedur Penelitian \\ Penentuan Lokasi Titik Sampling}

Lokasi pengambilan sampel air dan diatom epifit pada lamun E. acoroides ditentukan secara purposive sampling. Pantai Pandaratan akan dijadikan sebagai lokasi pengambilan sampel, penentuan lokasi titik sampling melalui beberapa pertimbangan oleh peneliti berdasarkan sumber pencemar dan juga kriteria kondisi perairan. Lokasi penelitian akan dibagi atas tiga titik stasiun yang dianggap dapat mewakili daerah penelitian. Stasiun 1 (Titik Koordinat: $01^{\circ} 43^{\prime} 16,85^{\prime \prime}$ LU; 98 $47^{\circ}$ '02,75" BT) di daerah sekitar jalur transportasi laut, stasiun 2 (Titik Koordinat: 01 ${ }^{\circ} 43^{\prime} 12,36$ " LU; 98 47'01,17' BT) di daerah dekat aktivitas industri perikanan, dan stasiun 3 (Titik Koordinat: $01^{\circ} 43^{\prime} 03,51^{\prime \prime} \quad$ LU; 9846'54,94" BT) di daerah yang jauh dari aktivitas manusia.

\section{Pengambilan dan Penanganan Sampel Minyak}

Pengambilan sampel air dan minyak dilakukan secara bersamaan di permukaan perairan dengan menggunakan botol sampel 1000 ml. Pengambilan sampel akan dilakukan sebanyak tiga kali pengulangan. Botol yang telah berisi sampel ditambahkan 2 tetes $\mathrm{H}_{2} \mathrm{SO}_{4}$ pekat, kemudian diberi label. Sampel air yang sudah ada dimasukan ke dalam ice box, diberi es dan dibawa ke laboratorium dan langsung dianalisis kandungan minyaknya [5].

\section{Pengambilan dan Penanganan Sampel Diatom}

Pengambilan sampel diatom dilakukan pada waktu siang hari yaitu antara pukul 11.00-15.00 WIB, karena pada waktu tersebut diperkirakan diatom berada 
di permukaan untuk melakukan fotosintesis [6]. Pengambilan sampel diatom epifit merujuk pada [7] yaitu: setiap stasiun diambil 3 titik yang mewakili komunitas lamun, setiap titik diambil secara acak 3 contoh dengan memotong tiga lembar daun lamun jenis $E$. acoroides dari tegakan yang berbeda. Pengambilannya dengan cara mengerik permukaan daun lamun (permukaan atas dan permukaan bawah) menggunakan sikat dan disemprot dengan larutan aquades agar sampel diatom epifit yang didapat maksimal dan tidak ada diatom epifit yang jatuh (sehingga volume konsentrat dalam botol sampel menjadi 30 ml) kemudian dimasukkan ke dalam botol sampel serta diberi larutan lugol dengan konsentrasi $4 \%$ dan diberi label.

\section{Analisis Kandungan Minyak}

Analisis kandungan minyak menggunakan metode ekstrak $\mathrm{CCL}_{4}$ berdasarkan petunjuk American Petroleum Institute yang dikenal dengan metode API 1340 [8]. Dalam penelitian ini minyak yang diukur adalah total hidrokarbonnya, dengan langkah kerja sebagai berikut: Sampel air laut yang telah diambil sebanyak 1 liter dari setiap stasiun dimasukkan ke corong pisah kemudian diekstrak dengan $25 \mathrm{ml} \mathrm{CCL}_{4}$ sampai tiga kali dan setiap hasil ekstraksi ditampung dalam erlenmeyer dan disaring terlebih dahulu dengan menggunakan glass wool. Hasil dari penyaringan, diukur volumenya $(\mathrm{C} / \mathrm{ml})$, dan hasil ekstraksi dipisahkan ke dalam labu (colf) yang terlebih dahulu sudah diketahui beratnya (dicuci bersih, dibilas dengan aquades dan dipanaskan dalam oven selama 1 jam pada suhu $105^{\circ} \mathrm{C}$ dan didinginkan dalam desikator selama 30 menit -1 jam), kemudian ditimbang (B gram), dan hasil ekstraksi yang dipindahkan ke dalam labu tersebut kemudian dipanaskan pada suhu $90^{\circ} \mathrm{C}$ sampai $\mathrm{CCL}_{4}$ menguap. Setelah menguap, ekstrak yang diperoleh dimasukkan ke dalam desikator selama 30 menit - 1 jam. kemudian labu ditimbang pada ketelitian 4 desimal (A gram)

$$
\text { Kadar Minyak }(p p m)=\frac{(A-B) X 75 \mathrm{ml}}{\mathrm{C} \text { x } 1000}
$$

Keterangan:

$$
\begin{aligned}
\mathrm{A}= & \text { Berat labu yang berisi ekstraks } \\
& \text { setelah } \mathrm{CCL}_{4} \text { menguap (gram) } \\
\mathrm{B}= & \text { Berat labu kosong (gram) } \\
\mathrm{C}= & \text { Volume } \mathrm{CCL}_{4} \text { setelah diekstraksi } \\
& (\mathrm{ml})
\end{aligned}
$$

\section{Analisis Kelimpahan Diatom}

Pengamatan dilakukan di laboratorium dengan menggunakan pipet tetes setelah diaduk rata terlebih dahulu, sebanyak 0,06 ml lalu diamati di bawah mikroskop binokuler dengan 3 kali pengulangan, dilakukan pada semua sampel. Setiap diatom yang didapat diidentifikasi dengan berpedoman pada buku [9-10]. Kelimpahan diatom epifit dihitung dengan menggunakan metode 12 lapang pandang merujuk pada rumus [11] sebagai berikut:

Keterangan:

$$
\mathrm{N}=\frac{3 \mathrm{Oi}}{\mathrm{Op}} \times \frac{\mathrm{Vr}}{3 \mathrm{Vo}} \times \frac{\mathrm{n}}{3 \mathrm{p}}
$$

$$
\begin{aligned}
\text { DT } & =\begin{array}{l}
\text { Jumlah Diatom Per Satuan Luas } \\
\left(\text { ind } / \mathrm{cm}^{2}\right)
\end{array} \\
\mathrm{Oi} & =\begin{array}{l}
\text { Luas Gelas Penutup }\left(484 \mathrm{~mm}^{2}\right) \\
\mathrm{Op}
\end{array}=\begin{array}{l}
\text { Luas Satuan Pandang }(1,306 \\
\left.\mathrm{mm}^{2}\right)
\end{array} \\
\mathrm{Vr} & =\begin{array}{l}
\text { Volume Larutan dalam Botol } \\
\text { Sampel }(30 \mathrm{ml})
\end{array} \\
\mathrm{Vo} & =\text { Volume } 1 \text { Tetes Sampel }(0,06 \mathrm{ml}) \\
\mathrm{A} & =\text { Luas Bidang Kerikan }\left(300 \mathrm{~cm}^{2}\right) \\
\mathrm{n} & =\text { Jumlah Diatom Epifit yang } \\
\mathrm{P} & =\text { Terambil }
\end{aligned}
$$

\section{HASIL DAN PEMBAHASAN \\ Keadaan Umum Lokasi Penelitian}

Pantai Pandaratan terletak di Kelurahan Pondok Batu, Kecamatan Sarudik, Kabupaten Tapanuli Tengah. Pantai yang berjarak sekitar satu kilometer 
dari dari kota Sibolga ini berpotensi sebagai objek wisata, selain memiliki pantai dengan hamparan pasir putih disekitar Pantai Pandaratan juga terdapat gua karang yang alami serta air terjun kecil. Pantai yang diakses dengan cara mendaki dan menuruni bukit ini masih belum mendapatkan perhatian khusus dari Pemerintah Tapanuli Tengah, terlihat dari belum adanya sarana dan prasarana yang mendukung potensi Pantai Pandaratan tersebut, serta akses menuju pantai yang rusak parahmenjadi salah satu kendala utama pengunjung yang ingin berdatangan.

\section{Kandungan Minyak di Perairan Pantai Pandaratan}

Minyak merupakan salah satu parameter penting dalam pendugaan pencemaran perairan, khususnya untuk wilayah seperti halur transportasi kapalkapal, dan pemukiman. Kandungan minyak yang didapat dari masing-masing stasiun sebagai berikut:

Tabel 1. Rata-rata Kandungan Minyak di Perairan Pantai Pandaratan (ppm)

\begin{tabular}{cccc}
\hline Stasiun & Titik Sampling & Kandungan Minyak & $\begin{array}{c}\text { Rata-rata Minyak } \\
\mathbf{\pm} \text { St. Dev }\end{array}$ \\
\hline \multirow{2}{*}{1} & 1 & 0,30 & \\
& 2 & 0,19 & $0,25 \pm 0,06$ \\
\hline \multirow{2}{*}{2} & 3 & 0,25 & \\
& 1 & 0,17 & $0,22 \pm 0,08$ \\
\hline \multirow{2}{*}{3} & 2 & 0,18 & \\
& 3 & 0,31 & $0,16 \pm 0,04$ \\
\hline
\end{tabular}

Tabel 1 diketahui bahwa total kandungan minyak tertinggi terdapat pada daerah sekitar jalur trasportasi laut (stasiun 1) yaitu sebesar $0,25 \mathrm{ppm}$ sedangkan kandungan minyak terendah ditemukan pada daerah yang jauh dari aktivitas manusia (stasiun 3) yaitu sebesar 0,16 ppm Tingginya kandungan minyak pada stasiun 1 dikarenakan stasiun ini terletak di daerah sekitar jalur transportasi laut, sumber minyak diduga berasal dari aktivitas kapal baik kapal-kapal yang bersandar atau kapal-kapal yang melintas yang memungkinkan adanya tumpahan minyak ke perairan. Selain itu kandungan minyak juga diduga berasal dari aktivitas kapalkapal nelayan misalnya kegiatan penangkapan ikan dan pembuangan air kapal serta dari bongkar muat hasil tangkapan dan pengisian bahan bakar. Hal tersebut sesuai dengan pernyataan [12] bahwa pencemaran minyak dapat terjadi dari beberapa sumber diantaranya aktivitas pelayaran dan aktivitas pelabuhan. Sedangkan total kandungan minyak di stasiun 3 merupakan nilai rata-rata yang paling rendah dibandingkan dengan Stasiun lainnya, hal ini diduga karena letak stasiun 3 yang jauh dari aktivitas manusia. Dimana pada kawasan ini tidak digunakan untuk aktivitas pelayaran maupun aktivitas industri perikanan. Dalam hal ini [13] menyatakan bahwa semakin jauh dari sumbernya maka kandungan minyak di perairan akan semakin menurun. Nilai kandungan minyak di perairan Pantai Pandaratan berdasarkan stasiun dapat dilihat pada Gambar 1.

Berdasarkan uji statistik One Way Anova total kandungan minyak pada setiap stasiun menunjukkan nilai $\mathrm{p}>0.05$ yaitu 0.256. Nilai tersebut menyatakan bahwa total kandungan minyak antar stasiun tidak berbeda nyata 


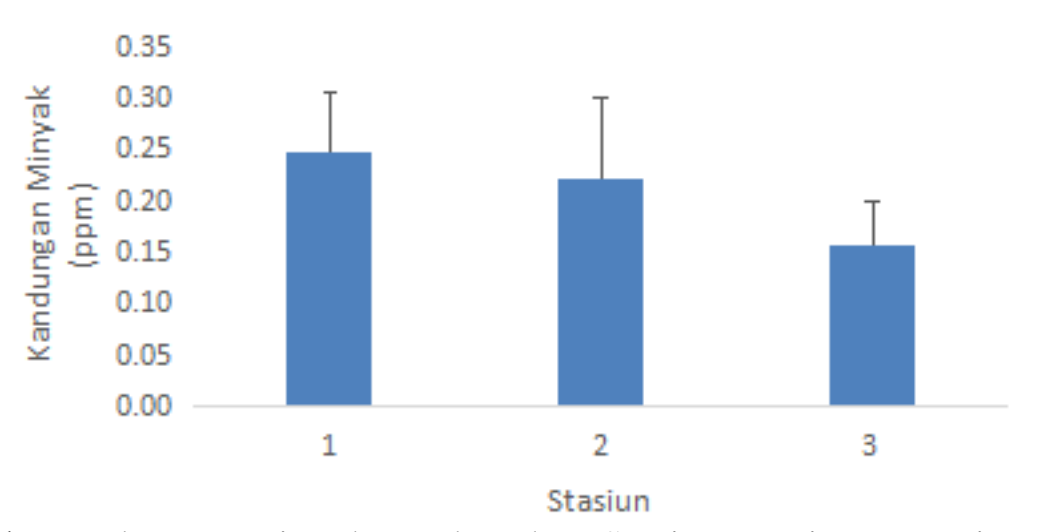

Gambar 1. Kandungan Minyak Berdasarkan Stasiun Perairan Pantai Pandaratan

\section{Kelimpahan Diatom Epifit di Perairan} Pantai Pandaratan

Jenis diatom yang ditemukan di daun lamun E. acoroides perairan Pantai Pandaratan berdasarkan stasiun sangat bervariasi, yang dapat dilihat pada Tabel 2, dapat diketahui bahwasanya spesies yang paling ditemukan pada setiap stasiun yaitu Nitzschia sp, Pinnularia sp, Oschillatoria sp dan Navicula sp. Kelimpahan diatom epifit di perairan Pantai Pandaratan berkisar antara 663,41 - 932,21 ind $/ \mathrm{cm}^{2}$ dengan kelimpahan tertinggi ditemukan pada daerah yang jauh dari aktivitas manusia (stasiun 3) yaitu 932,21 ind $/ \mathrm{cm}^{2}$, sedangkan yang terendah pada daerah sekitar jalur trasportasi laut (stasiun 1) yaitu 663,41 ind $/ \mathrm{cm}^{2}$ (Gambar 2).

Tabel 2. Jenis Diatom yang di temukan di daun lamun E. acoroides perairan Pantai Pandaratan Berdasarkan Stasiun

\begin{tabular}{lllcc}
\hline \multirow{2}{*}{ No } & Spesies & \multicolumn{3}{c}{ Stasiun } \\
\cline { 2 - 5 } & Nitzschia $\mathrm{sp}$ & $\mathbf{1}$ & $\mathbf{2}$ & $\mathbf{3}$ \\
\hline $\mathbf{1}$ & Pinnularia $\mathrm{sp}$ & + & + & + \\
$\mathbf{2}$ & Oschillatoria $\mathrm{sp}$ & + & + & + \\
$\mathbf{3}$ & Navicula $\mathrm{sp}$ & + & + & + \\
$\mathbf{4}$ & Amphora $\mathrm{sp}$ & - & + & + \\
$\mathbf{5}$ & Pleurosigma $\mathrm{sp}$ & - & + & - \\
$\mathbf{6}$ & Lauderia $\mathrm{sp}$ & - & + & + \\
$\mathbf{7}$ & Coscinodiscus $\mathrm{sp}$ & + & - & + \\
$\mathbf{8}$ & Isthmia $\mathrm{sp}$ & + & - & - \\
$\mathbf{9}$ & Rhizosolenia $\mathrm{sp}$ & + & + & - \\
$\mathbf{1 0}$ & Coconeis $\mathrm{sp}$ & - & - & - \\
$\mathbf{1 1}$ & & - & - & + \\
\hline
\end{tabular}

Keterangan : + : Ditemukan, - : Tidak ditemukan

Berdasarkan Tabel 2 Kelimpahan diatom tertinggi terdapat pada stasiun 3 hal ini dikarenakan stasiun ini berada pada daerah yang jauh dari aktivitas manusia dan diduga kandungan minyak pada stasiun ini tidak terlalu tinggi, sehingga lapisan minyak di permukaan air tidak menghalangi cahaya matahari masuk ke dalam perairan serta tidak mengganggu proses fotosintesis pada diatom. Sedangkan kelimpahan diatom epifit yang terendah ditemukan pada stasiun 1 , hal ini diduga karena pada stasiun ini suhu yang tinggi yaitu $32,3^{\circ} \mathrm{C}$ sehingga menghambat 
pertumbuhan diatom epifit. Sesuai dengan [14] menyatakan bahwa suhu berperan sebagai pengatur proses metabolisme dan fungsi fisiologis diatom.
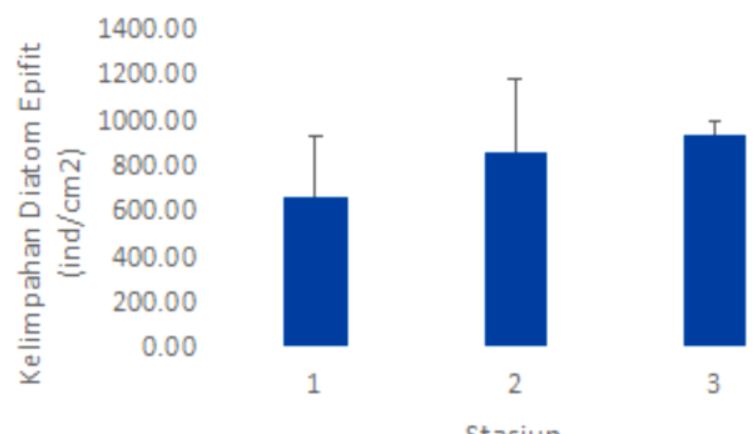

Stasiun

Gambar 2. Grafik Rata-rata Kelimpahan Diatom Berdasarkan Stasiun Perairan Pantai

Berdasarkan uji statistik One Way Anova yaitu kelimpahan diatom epifit pada setiap stasiun menunjukkan nilai $\mathrm{p}>0.05$ yaitu 0.220. Nilai tersebut menyatakan bahwa kelimpahan diatom epifit antar Stasiun tidak berbeda nyata.
Hubungan Total Kandungan Minyak dengan Kelimpahan Diatom Epidit pada Perairan Pantai Pandaratan

Hubungan rata-rata total kandungan minyak dengan kelimpahan diatom epifit pada ketiga stasiun di perairan Pantai Pandaratan dapat dilihat pada Gambar 3.

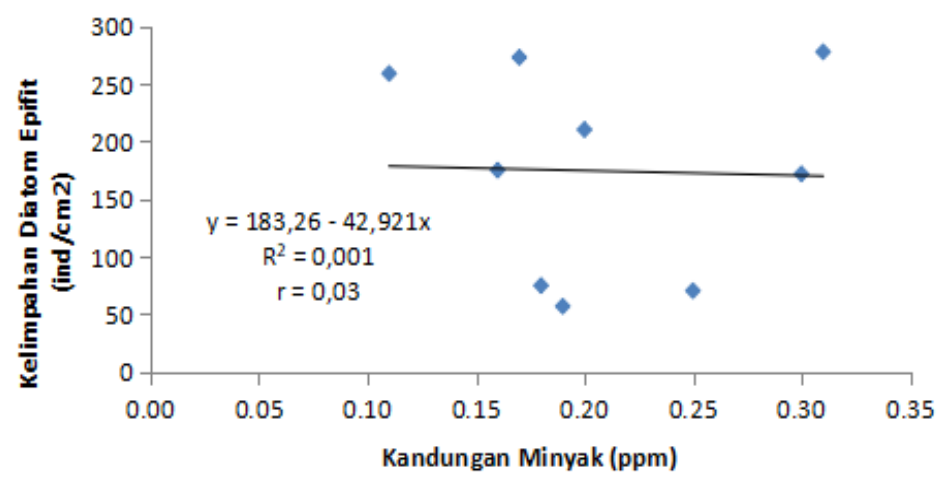

Gambar 3. Grafik Hubungan Total Kandungan Minyak dengan Kelimpahan Diatom Epifit di Perairan Pantai Pandaratan

Berdasarkan hasil uji regresi total kandungan minyak dan kelimpahan diatom epifit diperoleh persamaan matematis $\mathrm{y}=$ 183,26 - 42,921x dengan koefisien determinasi $\mathrm{R}^{2}=0,001$ dan koefisien relasi $r=0,03$. Nilai $r$ menyatakan hubungan yang sangat lemah. Sesuai dengan [15] kandungan minyak dengan kelimpahan diatom epifit dapat dikatakan memiliki hubungan yang sangat lemah apabila nilai koefisien korelasi (r) yaitu 0,00-0,20. Hal ini diduga kondisi aktivitas perairan yang sangat aktif sehingga dari aktivitas pelayaran mempengaruhi penyebaran minyak serta parameter kualitas perairan lainnya seperti nitrat, fosfat, salinitas, suhu, gelombang, arus, angin, dan pasang surut. Berdasarkan persamaan tersebut diketahui pengaruh kandungan minyak terhadap diatom epifit sebesar 3\%. Hal ini menunjukkan bahwa total kandungan minyak tidak banyak mempengaruhi kelimpahan diatom pada perairan Pantai Pandaratan. 


\section{KESIMPULAN DAN SARAN Kesimpulan}

Total kandungan minyak di perairan Pantai Pandaratan berkisar antara 0,16 $0,25 \mathrm{ppm}$ dengan total kandungan minyak tertinggi terdapat pada daerah sekitar jalur trasportasi laut (stasiun 1) yaitu 0,25 ppm dan terendah terdapat pada daerah yang jauh dari aktivitas manusia (stasiun 3 ) yaitu 0,16 ppm. Kelimpahan diatom epifitdi perairan Pantai Pandaratan berkisar antara 663,41 - 932,21 Ind $/ \mathrm{cm}^{2}$ dengan kelimpahan tertinggi ditemukan pada daerah yang jauh dari aktivitas manusia (stasiun 3) yaitu $932,21 \mathrm{Ind} / \mathrm{cm}^{2}$ dan kelimpahan terendah ditemukan pada daerah sekitar jalur trasportasi laut (stasiun 1) yaitu $663,41 \mathrm{Ind} / \mathrm{cm}^{2}$. Hubungan total kandungan minyak dan kelimpahan diatom epifit di Perairan Pantai Pandaratan Kabupaten Tapanuli Tengah Provinsi Sumatera Utara adalah sangat lemah $(\mathrm{r}=0,03)$.

\section{Saran}

Pada penelitian ini analisis yang dilakukan hanya hubungan total kandungan minyak terhadap kelimpahan diatom epifit. Sehingga perlu adanya penelitian lanjutan mengenai hubungan bahan organik dengan diatom atau hubungan kandungan minyak terhadap zooplankton/makrozoobenthos dan diharapkan kepada pemerintah dan masyarakat setempat untuk dapat bersamasama menjaga lingkungan perairan agar terhindar dari perairan yang tercemar.

\section{DAFTAR PUSTAKA}

1. Budi, A.Y. (2017). Hubungan Kandungan Minyak dengan Kelimpahan Diatom Di Perairan Tanjung Balai Karimun Kabupaten Karimun Provinsi Kepulauan Riau. Skripsi Fakultas Perikanan dan Ilmu Kelautan Universitas Riau. Pekanbaru.

2. Lianov, D., Efriyeldi, dan Zulkifli. (2019). Density and Coverage of Seagrass on Different Type of Sediment at Pandaratan Beach Tapanuli Tengah Regency North Sumatera Province. Asian Journal of Aquatic Sciences, 2(2): 138-144

3. Banjarnahor, N., J. Samiaji, dan S. Nasution. (2021). Effect of Sediment Particle Sizes on the Density and Morphometrics of Seagrass Enhalus acoroides Leaves at Pandaratan Beach Tapanuli Tengah. Journal of Coastal and Ocean Sciences, 2(1): 5360

4. Kiswara, W. (1992). Community Structure and Biomass Distribution of Seagrass at Banten Bay, West Java, Indonesia.

5. Evary, L.V. (2010). Kandungan Minyak Pada Saat Pasang dan Surut di Perairan Kawasan Industri Dumai. Skripsi Fakultas Perikanan dan Ilmu Kelautan Universitas Riau. Pekanbaru. $46 \mathrm{hlm}$.

6. Nurrachmi, I., J. Samiaji dan A. Mulyadi. (2014). Planktonologi Laut. Bahan Ajar Perkuliahan Planktonologi Laut Jurusan Ilmu Kelautan Fakultas Perikanan dan Ilmu Kelautan Universitas Riau.

7. Nagle, J.S. (1968). Distribution of the epibiota of macroepibenthic plants. Univ. Texas. Contri. Mar. Sci. 13: 105-114

8. Margaretha, H., S. (2014). Analisis Kandungan Minyak dan Kelimpahan Diatom Planktonik di Perairan Pantai Medan Kota Belawan Sumatera Utara. Skripsi Fakultas Perikanan dan Ilmu Kelautan Universitas Riau. 86 Hal. (Tidak Diterbitkan).

9. Davis. (1955). The Marine and Fresh Water Plankton. Michigan State University Press. United State of America.

10. Yamaji, I. (1996). Ilustration of Marine Plankton of Japan. Hoikusha Publishing Co. Ltd. Japan. 
11. [APHA] American Public Health Association. 2005. Standart Methods for The Examination of Water and Waste Water, 16th Edition. Washington DC. 76 Pages.

12. Malisan, J. (2011). Kajian Pencemaran Laut dari Kapal dalam Rangka Penerapan PP Nomor 21 Tahun 2010 Tentang Perlindungan Lingkungan Laut. Jurnal Penelitian Tranpostasi Laut, 13(1), 65-77.

13. Amin, B. (1996). Studi Tentang Kondisi Fisika-Kimia Perairan di Sekitar Dumai Marine Station, Selat Rupat dan Selat Malaka. Laporan Penelitian Universitas Riau Pekanbaru. 56 hlm (tidak diterbitkan)

14. Welch, E.B. (1980). Ecological Effects of Waste Waster. Cambrige University Press. Cambrige. 337

15. Razak, A. (1991). Statistika Bidang Pendidikan. Fakultas Keguruan dan Ilmu Pendidikan Universitas Riau. Pekanbaru. 98 hlm 